\title{
Credit Risk Management: An Empirical Study on BRAC Bank Ltd.
}

\author{
Proshenjit Ghosh \\ Customer Service Manager, BRAC Bank Limited \\ House-1, Road-15, Sector-3, Uttara, Dhaka, Bangladesh \\ Tel: 88-017-1252-3119Ｅ-mail: proshenjit_ghosh@yahoo.com
}

\author{
Md. Ariful Islam \\ Deputy Manager, BASIC Bank Ltd. \\ 107, Sir Iqbal Road, Khulna, Bangladesh \\ Tel: 88-017-1752-9503Ｅ-mail: arifrussell@yahoo.com
}

Md. Moeid Hasan

Masters of Business Administration

BRAC University, Bangladesh

Tel: 88-017-1825-5007Ｅ-mail: moeidhasan@yahoo.com

Received: November 23, 2013 Accepted: February 19, $2014 \quad$ Published: June 5, 2014

doi:10.5296/bms.v5i1.4618ＵRL: http://dx.doi.org/10.5296/bms.v5i1.4618

\begin{abstract}
Credit Risk Management holds a positive relationship with credit monitoring, reliability and assurance factors. All these factors play vital role in the mitigation process of credit risks. Risk mitigation process starts from sourcing loan applications and the loan application goes through several screening process where reliability and assurance factors are very much important. Here, knowledge of practical world and product program are very much essential to identify risks associated with loan proposals. With the centralized banking system BRAC
\end{abstract}




\section{Macrothink}

Business Management and Strategy

ISSN 2157-6068 2014, Vol. 5, No. 1

Bank deals with a systematic lending procedure which follows an straightforward policy. This type of policy helps the analysts to analyze loan proposals very easily. But there are some weak points of this straightforward policy and guidelines. This procedure deny any type of exceptional proposals which may have better creditworthiness and repayment capacity. Business is lost in these situations which is treated as opportunity cost. In a word, credit risk management is all about ensuring repayment capability of the customers who are provided loans and advances. Minimizing Credit Risk is subject to proper framework of risks and justification with historical trend and other assurance factors.

Keywords: Credit Risk Management, BRAC Bank Ltd., Credit Risk Assessment, Credit Monitoring, Assurance Factor, Reliability 


\section{Introduction}

\subsection{Background of the Study}

Credit Risk Management can be treated as the heart of any Commercial Bank. It plays the vital role in the performance of a financial institution as it analyzes creditworthability of borrowers. If there is any loophole in credit risk assessment, then recovery of the provided loans and advances is challenged greatly. As a whole, profitability falls in a great uncertainty. A bad loan often arises from different factors or combination of factors, but the most important reason is the absence of proper loan classification system. It can identify problem loans immediately and take necessary steps to minimize potential defaults and consequent losses. Poor Credit Risk Management is the main consideration in case of Banks' unsatisfactory performance and often the reason of bankruptcy.

\subsection{Problem Statement}

Credit Risk Grading (CRG) is treated as the common credit risk measurement system in BRAC Bank Ltd. There are also other factors which influences the default risk of a loan. They are subject to mitigation.

- Credit Risk $>>>>>>>>>>>>>>>>>>>>$ Mitigation

- Process Risk $>>>>>>>>>>>>>>>>>>$ Mitigation

- IT System Risk $>>>>>>>>>>>>>>>>>$ Mitigation

- Foreign Exchange Risk $>>>>>>>>>>>>$ Mitigation

- Credit Sensitivity $>>>>>>>>>>>>>>>>$ Mitigation

- Compliance Risk $>>>>>>>>>>>>>>>$ Mitigation

- Internal \& External Fraud Risk $>>>>>>$ Mitigation

- Documentation Risk $>>>>>>>>>>>>>>$ Mitigation

- Operational Risk $>>>>>>>>>>>>>>>>$ Mitigation

\subsection{Objectives of the Study}

Lending is one of the main factors of Asset side of balance sheet of a bank. So, profitability of the bank is greatly involved with the lending procedure to borrowers. This report is equipped with critical observation of Loans and advancement division of BRAC Bank Ltd. Three factors are correlated with Credit Risk management system of BBL and hypothesis of these factors are treated as the primary tool for measuring performance Credit Risk Management Division of BBL. There are five wings in the Credit Risk Management Division of BBL. They are as follows:

- Wholesale Credit

- Retail Underwriting

- SME Underwriting

- Collection Unit (SME, Retail \& Cards)

- Credit Inspection \& Special Asset Management, Wholesale Banking \& Medium Business 


\subsubsection{Main Objective}

The primary objective of the study is to find out areas which are required to improve or incorporate for minimizing risks associated with each lending.

\subsubsection{Specific Objective}

- Relationship of Credit Risk with Credit Monitoring.

- Relationship of Credit Risk with Reliability.

- Relationship of Credit Risk with Assurance Factor.

- The extent to which BBL comprises with provided guideline for Risk measurement.

1.4 Conceptual Framework

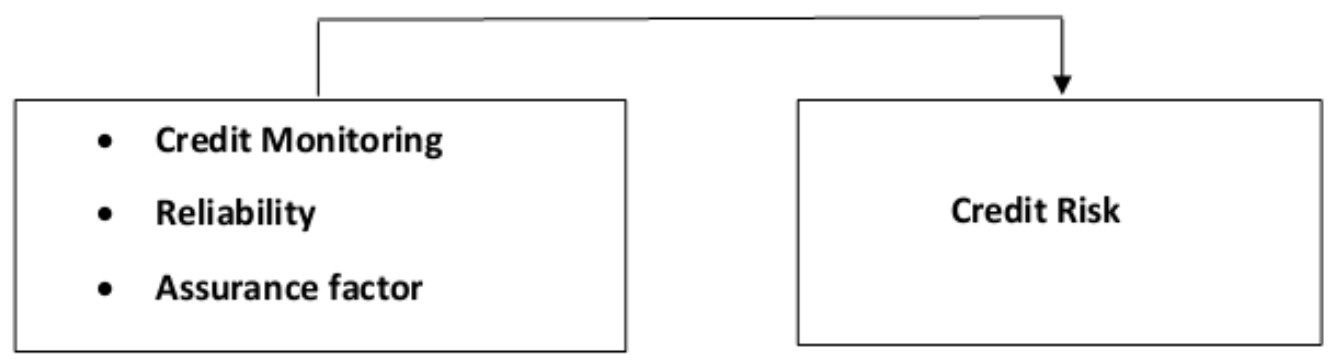

Figure 1. Three factors related with Credit Risk.

\subsubsection{Research Questions}

- Is there any significant relationship between Credit Risk and Reliability in context of BRAC Bank in Bangladesh?

- Is there any significant relationship between Credit Risk and Assurance factor in context of BRAC Bank in Bangladesh?

- Is there any significant relationship between Credit Risk and Credit Monitoring in context of BRAC Bank in Bangladesh?

\subsubsection{Research Questions Hypothesis}

- There is a significant relationship between Credit Risk and Reliability in context of BRAC Bank in Bangladesh.

- There is a significant relationship between Credit Risk and Assurance factor in context of BRAC Bank in Bangladesh.

- $\quad$ There is a significant relationship between Credit Risk and Credit Monitoring in context of BRAC Bank in Bangladesh. 


\subsection{Methodology of the Report}

Main objective is to find out specific correlationship between the independent and dependent variables associated in this research subject matter. Therefore, the objective is to look at the relationship between various services provided by credit department as well as proper and prior analysis of credit proposals of the same sector. For the purpose of the research, initially designed a descriptive-correlational study to assess whether there is any correlation among the variables.

The research has been carried out over a one period of time through questionnaires answered by the employees using the conventional method of personal interview. Further information used to prepare this report has been collected from both primary and secondary sources. The primary sources have provided the report with reliable data and information relating to local clients and the bank's operations. On the other hand, the secondary sources have been an indispensable source of information regarding the historical background of the bank, its function, and descriptions of its various departments and products.

\subsubsection{Primary Data}

- Data collected from the employees by personal interview conducted through questionnaires.

- Informal discussion with the banks staff, especially the credit division managers of corporate segment.

\subsubsection{Secondary Data}

- Annual report of BBL.

- Relevant data from the banks reports, presentations and other documents.

- $\quad$ Printed forms and documentation supplied by BBL.

- Different publications and journals regarding banking activities and policies.

- Head Office Circulars

- $\quad$ Auditors report of BBL.

- Intranet site of BBL

- Official local website of Bangladesh Bank.

\subsubsection{Sample Size}

The sample size consisted of 25 respondents who are the employees of the bank's respective department. In the CRM department of BBL has around 200 employes. As every employees 
are very busy with their daily works it was quite difficult to reach each employee for survey.

For this research, those employees were chosen who have maximum possibilities of answering the Survey questions. So, keeping limitations in mind, a sample size of 25 has bee n choosen from BBL.

\subsubsection{Sample Demographics}

\begin{tabular}{|l|l|l|}
\hline Type of Respondents & Numbers & In Percentage \\
\hline Senior Manager & 2 & 8 \\
\hline Manager & 3 & 12 \\
\hline Associate Manager & 5 & 20 \\
\hline Officer & 15 & 60 \\
\hline Total & 25 & 100 \\
\hline
\end{tabular}

\subsubsection{Data Analysis}

Analysis can be done for both qualitative and quantitative data. Cross Sectional Study has been done to limit the research to a reduced length. To analyze the data collected from the survey through qustionnaire are inputed in SPSS software. Correlations, Regression and reliability analysis was conducted through the software.

\section{Literatue Review}

\subsection{Credit Risk}

The risk of loss of principal or loss of a financial reward stemming from a borrower's failure to repay a loan or otherwise meet a contractual obligation. Credit risk arises whenever a borro wer is expecting to use future cash flows to pay a current debt. Investors are compensated for assuming credit risk by way of interest payments from the borrower or issuer of a debt obligat ion. Jarrow, Lando and Turnbull (1997) study the term structure of credit risk spreads in a mo del with the bankruptcy process following a discrete state space Marko chain in credit rating. Crouhy , Galai and mark(2000) make a comparison of Credit Risk to the other models, they st ate that credit risk is easy to apply as it drive a closed form solution for the loss distribution $o$ $\mathrm{f}$ a credit portfolio. There is no market risk in credit risk because both market risk and credit migration are ignored in this model, each borrowers exposure is the same changes in its credit quality do not affect its exposure.

\subsection{Credit Monitoring}

Credit Monitoring play crutial roles in achieving financial goals. Too conservative a policy will entail high opportunity cost through loss of business, but too li beral a policy results in the cost of tying up funds in debtors and the increased possibility of $b$ 
ad debts. A survey investigating building merchants' practices in Wales (1984), conducted by questionnaire, reflects some variety in approaching the provision of trade credit, but a relative ly high degree of uniformity and lack of sophistication in monitoring systems. Stigitz and Wei ss(1988) are the example of papers advancing the idea that banks are institutions specializing suggest that monitoring the behavior of customers over time including repayment of loans an $\mathrm{d}$ other transactions, provides banks with an information advantage they can use to successful ly perform the function of resource allocation in an economy.

\subsection{Reliability}

Risk is a growing concern in the modern environment and a number of disasters have served tofocus attention on the hazards and risks involved in a wide range of activities. There is a wide range of tecniques and procedures to find out risk and assess the reliability, both in relation to safety and in the wider sense. These techniques now underpin ne $\mathrm{w}$ legislation on safety and have relevance over a broad spectrum of activities, including envi ronmental and other systems, where risk and reliability are key concerns. Chee Tong (2001) S tructural risk and reliability analysis has been identified as the potential tool for satisfying the se requirements. It is capable of identifying the sources of variables affecting the fatigue life a nd fatigue strength of the structure in terms of risk.

\subsection{Assurance}

Douglas L. King and Rocie C. Wellman (1995) A system and method of accepting risk though contractual obligations transfer a portion of the risk to investors and includes means for absolute assurance of timely payment to contract holders, and segregation, of interests of particular investors to specifically identified risk in a risk to capital matching system, the syst em creates agreements which promise payments, Based on loss from risk including investme nt risk. Data processing provides legally segregated relationship management links, supervisi ng and balancing the interests of professionals in a Risk transfer and diversification system.

\section{Loans and Advances of BRAC Bank Ltd}

Loans and Advances makes profit for the bank. The bank collects deposit from general people with a cost paid to the depositors. The most important task for the bank is to disburse the collected deposit as loan and advances for the development of business firms and extension of business. Profitability of the bank depends on the proper identification of risk factors relatd with the repayment of the borrowers. Different lending products are designed to finance different types of borrowers according to their business type and needs. Some consumer loans are provided to individuals for meeting their personal needs like auto purchase, flat purchase and others. BBL segmented its lending products very efficiently by matching interest rates with business type and needs. Varieties of BBL loans are mentioned in the following way. 


\subsection{Classification of Loans}

- Corporate Credit Scheme.

- Retail Credit Scheme

- SME Credit Scheme

- Corporate Credit Scheme

The bank is entrusted with the responsibility of providing short, medium and long term loans and other financial assistance for promotion of industrial sectors. There are 10 types of corporate credit scheme:

- Overdraft, Short Term Loan, Lease Finance, Loan against trust Receipt(LATR), Work order finance, Emerging Business, Syndication, Term Loan, Project Finance, Bank Guarantees

- Retail Credit Scheme:

The bank also provides retail loan to individual customer. There are different types of retail loan which helps customer to fulfill their dream. There are 4 types of loan in retail credit scheme:

- $\quad$ Personal Loan, Auto Loan, Home Loan, Secured Loan/ Overdraft

- SME Credit Scheme:

BRAC Bank, being the youngest bank, took a step to break away from usual tradition and tapped into the true suburb entrepreneurial initiatives. Today, with over 220,139 million of loans disbursed till date, BRAC Bank is country's largest SME financier that has made more than 410,817 dreams come true. There are 6 types of SME Loan Scheme:

- Anonno Rin, Apurbo Rin, Prothoma Rin, Durjoy, Shomriddhi Rin, Shompod Rin, Shokti Rin

\subsection{Process: Wholesale Credit (Corporate \& Sme Medium)}

\# Wholesale Credit receives Credit Proposal with documents from Corporate Banking \& SME Medium Business.

\begin{tabular}{|l|l|}
\hline Wholesale Credit (Corporate \& SME Medium) & List of Required Documents(LRD) \\
\hline & As per Corporate Credit Policy. \\
\hline
\end{tabular}




\begin{tabular}{|l|l|}
\hline Wholesale Credit (Corporate \& SME Medium) & Control Point \\
\hline & $\begin{array}{l}\text { Wholesale Credit receives the following: } \\
\text { 1. Credit Proposal }\end{array}$ \\
& $\begin{array}{l}\text { 2. CRG Sheet } \\
\text { 3. FSS } \\
\text { 4. Search Report } \\
\text { 5.CIB Report }\end{array}$ \\
\hline
\end{tabular}

\# Wholesale Credit Analysts checks the Proposals for consistency and completeness.

\begin{tabular}{|l|l|}
\hline Wholesale Credit (Corporate \& SME Medium) & Control Point \\
\hline & $\begin{array}{l}\text { Checks the following thing: } \\
\text { 1.Emerging Unit Credit Proposals are } \\
\text { checked by Credit Analyst (Emerging). } \\
\text { 2.Large Unit Credit Proposals are checked t } \\
\text { (Large) } \\
\text { 3.Credit may ask for documents related to ac } \\
\text { (if \& when needed). }\end{array}$ \\
\hline
\end{tabular}

\# If any discrepancy is found, Wholesale Credit informs the respective RM about the discrepancy through lotus mail.

\# RM rectifies the discrepancies and sends the docs/rectified proposals to CRM.

\# If everything ok, Credit Analysts make recommendations (approve/ decline) of the Credit proposals depicting loan amount, tenor, Interest Rate and additional terms and condition (if any) and forward the Proposals to the Head of Credit Wholesale Banking \& Medium Business.

\# Head of Credit Wholesale Banking \& Medium Business approves/ decline/ recommends to Chief Credit Officer if not within the approval authority.

\begin{tabular}{|l|l|}
\hline Wholesale Credit (Corporate \& SME Medium) & Control Point \\
\hline & $\begin{array}{l}\text { Individual Credit Proposals other than } \\
\text { Board s approval authority may be } \\
\text { placed at Credit Committee Meeting } \\
\text { on a case to case basis for decision. }\end{array}$ \\
\hline
\end{tabular}


\# Chief Credit Officer approves/declines/ recommends to the Managing Director \& CEO if not within the approval authority.

\begin{tabular}{|l|l|}
\hline Wholesale Credit (Corporate \& SME Medium) & Control Point \\
\hline & $\begin{array}{l}\text { Individual Credit Proposals other than } \\
\text { Board s approval authority may be placed } \\
\text { at Credit Committee Meeting on a case to } \\
\text { case basis for decisionIndividual Credit } \\
\text { Proposals other than Board s approval } \\
\text { authority may be placed at Credit } \\
\text { Committee Meeting on a case to case } \\
\text { basis for decision }\end{array}$ \\
\hline
\end{tabular}

\# Managing Director \& CEO approve/ decline/ recommends to the Board if not within the approval authority.

\# Board approves/ declines the Credit Proposal at the monthly Board Meeting. Alternatively, they may also be approved by circulation.

\# The loans get approved as per Delegated Approval Authority subject to creditworthiness.

\begin{tabular}{|l|l|}
\hline Wholesale Credit (Corporate \& SME Medium) & Control Point \\
\hline & The following are usually considered for apF \\
& $\begin{array}{l}\text { 1.Respective Company’s Creditworthiness, I } \\
\text { justification } \\
\text { 2.CIB Report } \\
\\
\text { 3.Visit report (if \& when needed) }\end{array}$ \\
\hline
\end{tabular}

\# Wholesale Credit sends back the declined Credit Proposal to Corporate Banking Division/ SME Medium Business.

\#Wholesale Credit forward the approved Credit Proposals to the respective RM of Corporate Banking or SME Medium Business

\# RM prepares Sanction Advice as per approval term \& conditions and mails to Wholesale Credit for validation.

\# Wholesale Credit validates the sanction (Following the maker checker concept) and mails back to RM for print out and sign off.

\# RM prepares Sanction Advice as per approval term \& conditions and mails to Wholesale Credit for validation. 
\# Wholesale Credit validates the sanction (Following the maker checker concept) and mails back to RM for print out and sign off.

\section{Problem Identification}

- The Bank does not go through background investigation of all loan applications.

- $\quad$ Sometimes the loan documentation is not fairly done.

- $\quad$ Sometimes the document verification is done after loan sanction.

- $\quad$ In some cases loans are disbursed keeping documents deffered.

- $\quad$ In some cases loans are disbursed before mortgage of the proposed property.

- $\quad$ The Individual loan section is not so strong because they are focused on SME loan.

- $\quad$ To some extent Credit Analyst has limitation in knowledge as they never worked in front line where customer interactions were available.

- $\quad$ PPG of loan products are not reviewed frequently keeping pace with market changes.

\section{Findings}

Based on observation and interpretation it is found that BBL has some positive and negative side.They are given below:

- Bank Follows the overall credit assessment and risk grading process according to Bangladesh Bank’s policy and guideline in maximum cases.

- Loan and Advances are vital to the profitability of the Bank. An appropriate credit distribution system and monitoring will ultimately lead to the profit maximizing of the bank. It is evident that the size of BBL loans and advances are increasing over the years.

- $\quad$ BBL has a positive growth rate in Net profit.

- $\quad$ NPL is increasing over the time instead of excellent performance of collection and Sam team.

- $\quad$ PAR is also increasing with the flow of time.

- $\quad$ As per Bangladesh Bank guidelines proper provisioning should be done against classified loans. As a result profitability decreases. So, increase of the portfolio does not always mean increase in growth rate of net profit.

- $\quad$ To some extent all the assurance factors are not considered in PPG of loans. As a result, risk increases.

- Credit monitoring proceudure of BBL is quite satisfactory which is reflected in the decline trend of NPL. 


\section{Analytical Proof}

The survey is done by some Questioner, after collecting the data from survey questions; I use SPSS Software for data analysis which is quantitative data. Correlations, Regression, Reliability test is done by the use of spss for the variables.

Reliability test

\begin{tabular}{lll}
\hline Variables Name & N of items & Cronbach's Alpha \\
\hline Credit monitoring & 4 & .858 \\
Reliability & 4 & .617 \\
Assurance factor & 4 & .535 \\
\hline
\end{tabular}

Interpretation:

Alpha standard value is .5 for reliability. So, for credit monitoring the cronbach's Alpha is .858 so, $.858>.5$, it shows that the Questions are clear to the ordinance and also the Questions are reliable. For Reliability the Cronbach's Alpha is .617 and .617 > .5, it shows that the Questions are clear to the ordinance and also the Questions are reliable. For Assurance factor the Cronbach's Alpha is .535 and .535 > .5, it shows that the Questions are clear to the ordinance and also the Questions are reliable.

(Source: Perception of Power (book), chapter: 6, page: 149)

Correlations

\begin{tabular}{|c|c|c|c|c|}
\hline & Credit risk & Reliability & $\begin{array}{l}\text { Credit } \\
\text { monitoring }\end{array}$ & $\begin{array}{l}\text { Assurance } \\
\text { factor }\end{array}$ \\
\hline Credit risk & 1 & & & \\
\hline Reliability & $.855^{* *}$ & 1 & & \\
\hline $\begin{array}{l}\text { Credit } \\
\text { monitoring }\end{array}$ & $.946^{* *}$ & $.687 * *$ & 1 & \\
\hline $\begin{array}{l}\text { Assurance } \\
\text { Factor }\end{array}$ & $493 *$ & .168 & $.422 *$ & 1 \\
\hline
\end{tabular}

**. Correlation is significant at the 0.01 level (2-tailed).

*. Correlation is significant at the 0.05 level (2-tailed).

Interpretation:

The value .855 is positive number, if the variable is increased by one unit the other variable will increase by +.855 . Also the value contents 2 star, so it means the relation between credit risk and reliability is moderately significant. .855 is "between" .7 to .9 so; the strength is strong, high and marked. We can explain other correlation in same way.

(Source: Perception of Power (book), chapter: 6, page: 133) 
Regression

\begin{tabular}{llll} 
Model & Variables Entered & $\mathrm{R}$ & $\mathrm{R}$ square Change \\
\hline 1 & Credit monitoring & $.946 \mathrm{a}$ & .896 \\
2 & Reliability & $.987 \mathrm{~b}$ & .079 \\
3 & Assurance factor & $1.000 \mathrm{c}$ & .025
\end{tabular}
a.Predictors: (Constant), Credit monitoring
b.Predictors: (Constant), Credit monitoring, Reliability
c.Predictors: (Constant), Credit monitoring, Reliability, Assurance factor

Interpretation:

$\mathrm{R}$ square for credit monitoring is .896. So, credit monitoring (independent variable) can explain credit risk (dependent variable) $89.6 \%$. R square for reliability is .097. So, Reliability can explain credit monitoring $7.9 \%$. R square for assurance is .025 . So, assurance factor can explain credit risk $2.5 \%$.

(Source: Perception of Power (book), chapter: 6, page: 152)

After analysis of all the data by the use of SPSS the result shows that the correlation between these four variables is more or less moderately significant, significant and also the strength between the variable is very strong, high and marked. From the regression we can define that the independent variables can explain credit risk (dependent variable) by high percentage. After the reliability test the result of all the variables shows that the Cronbach's alpha for all variables is grater then .5 which means all the questions are clear and reliable to the ordinance.

\section{Conclusion}

Though questions were relatively less in number, there had a chance to express respondents' views openly about credit assessment, credit rating policies and overall credit risk management. Both qualitative and quantitative methods were used to analyze BBL Credit Risk Management. A bank should consider numerous factors, including cost, efficiency of information gathering, consistency of rating produced, staff incentives, nature of a bank's business, and uses to be made of the internal ratings. While assigning a loan applicant to a particular grade, consideration in three different categories of variables are requiredquantitative, qualitative and legal. The quantitative analysis concentrates mainly on financial analysis and is often based on a firm's financial reports. Credit monitoring, reliability and assurance factor play a crucial roles in achieving financial goals and also minimize their credit risk. BBL gives enough importance to the credit monitoring area, all the officer of 
credit monitoring department are well aware of this factor. BBL always tries to find out their reliable customer and reliability factor which help to increase the number of reliable customer.

\section{References}

Bangladesh Bank. (1996). Guidelines for Credit Management of Bangladesh Bank. Retrieved from http://www.bangladesh-bank.org

Bangladesh Bank. (2008-2009). Credit Management Policy Order of 2008 - 2009. Retrieved from http://www.bangladesh-bank.org

Cooper, Donald R. Schindler, \& Palmer. S. (2009). Business Research Methods (9th Ed). McGraw Hill.

Crouhy, Galai \& Mark (2000). A comparative analysis of Current Credit Risk Models. Journal of Banking \& Finance, 24(2000). http://dx.doi.org/10.1016/S0378-4266(99)00053-9

Crouhy, Galai, \& Mark (2001). Prototype Risk Rating System. Journal of Banking and Finance, 25, 47-95. http://dx.doi.org/10.1016/S0378-4266(00)00117-5

Focus group. (2007). Credit Risk Management, Industry Best Practices. Retrieved from http://www.bangladesh-bank.org/mediaroom/corerisks/creditrisk.pdf

Industrial Engineering and Operation Research. (1997). A Markov Model for the Term Structure of Credit Risk Spreads. Retrieved from http://www.ieor.berkeley.edu/ ieor298/Reading/JarrowEtAl-97.pdf

Mark D. Wenner (1995). A Means to Improve Information transfer And Loan Repayment Performance. Frank Cass London, 34(1995).

Monetary Authority of Macao. (2013, July 10). Internal Credit Risk Rating Systems in the Macao Banking Sector. Retrieved From Monetary Authority of Macao:

http://www.amcm.gov.mo/publication/quarterly/Jan2007/!\%20InternalCredit_en.pdf\%20(200 70214)

Rural Development Bank. (2013, July15). A Loan Assessment System for Centenary Rural Development Bank. Retrieved from http://dspace.mak.ac.ug/bitstream/123456789/617/3/nassali-josephine-cit- masters-report.pdf

Siddique and Islam (2001). Banking Sector in Bangladesh: Its Contribution and Performance. Journal of Business Research, 3, 2001.

Treacy, W. F., \& S. M. Carey. (2000). Credit Risk Rating System at Large U.S. Banks. Journal of Banking and Finance, 24, 167-201. http://dx.doi.org/10.1016/S0378-4266(99)00056-4 


\section{Macrothink}

\section{Appendix}

Appendix 1.

Abbreviations

BBL BRAC Bank Limited

CRM Credit Risk Management

NPL Non Performing Loan

PAR Portfolio at Risk

CRG Credit Risk Grading

SME Small and Medium Enterprises

IT Information Technology

Appendix 2.

Credit Risk Grading (CRG)

Manual of Bangladesh Bank was circulated by Bangladesh Bank vide BRPD Circular No. 18 dated December 11, 2005 on Implementation of Credit Risk Grading Manual which is primarily in use for assessing the credit risk grading before a bank lend to its borrowing clients.

Well-managed credit risk grading systems increases bank safety by facilitating informed decision-making. Grading systems measure credit risk and differentiate individual credits and groups of credits by the risk they pose. This allows bank management and examiners to monitor changes and trends in risk levels. The process also allows bank management to manage risk to optimize returns. 


\begin{tabular}{|c|c|c|c|}
\hline Number & Risk Grading & Short Name & Score \\
\hline 1 & Superior & SUP & $\begin{array}{l}\text { - } \quad 100 \% \text { cash covered } \\
\text { - } \quad \text { Government guarantee } \\
\text { - } \quad \text { International Bank } \\
\quad \text { guarantees }\end{array}$ \\
\hline 2 & Good & GD & $85+$ \\
\hline 3 & Acceptable & ACCPT & $75-84$ \\
\hline 4 & $\begin{array}{l}\text { Marginal/Watch } \\
\text { list }\end{array}$ & MG/WL & $65-74$ \\
\hline 5 & $\begin{array}{l}\text { Special } \\
\text { Mention }\end{array}$ & $\mathrm{SM}$ & $55-64$ \\
\hline 6 & Sub-standard & SS & $45-54$ \\
\hline 7 & Doubtful & DF & $35-44$ \\
\hline 8 & Bad \& Loss & BL & $<35$ \\
\hline
\end{tabular}

(Source: CREDIT RISK GRADING MANUAL of Bangladesh Bank)

Data Analysis

Correlation

\begin{tabular}{|c|c|c|c|c|c|}
\hline & & Cred it risk & Reliability & $\begin{array}{l}\text { Credit } \\
\text { monitoring }\end{array}$ & $\begin{array}{l}\text { Assurance } \\
\text { factor }\end{array}$ \\
\hline \multirow{3}{*}{ Credit risk } & Pearson Correlation & 1 & $.855^{\circ}$ & $.946^{\circ}$ & $493^{\circ}$ \\
\hline & Sig. (2-tailed) & & .000 & .000 & .012 \\
\hline & $\mathrm{N}$ & 25 & 25 & 25 & 25 \\
\hline \multirow{3}{*}{ Reliability } & Pearson Correlation & $.855^{* \prime}$ & 1 & $.687^{* *}$ & .168 \\
\hline & Sig. (2-tailed) & .000 & & .000 & .422 \\
\hline & $\mathrm{N}$ & 25 & 25 & 25 & 25 \\
\hline \multirow{3}{*}{ Credit monitoring } & Pearson Correlation & $946^{\prime \prime}$ & $.687^{\prime \prime}$ & 1 & $.422^{\circ}$ \\
\hline & Sig. (2-tailed) & .000 & .000 & & .035 \\
\hline & $\mathrm{N}$ & 25 & 25 & 25 & 25 \\
\hline \multirow{3}{*}{ Assurance factor } & Pearson Correlation & $493^{\circ}$ & .168 & $.422^{\circ}$ & 1 \\
\hline & Sig. (2-tailed) & .012 & .422 & .035 & \\
\hline & $\mathrm{N}$ & 25 & 25 & 25 & 25 \\
\hline
\end{tabular}

Regression 
Variables Entered/Removed ${ }^{2}$

\begin{tabular}{|c|c|c|c|}
\hline Model & Variables Entered & Variables Removed & Method \\
\hline 1 & Credit monitoring & . & $\begin{array}{l}\text { Stepwise (Criteria: Probability-of-F-to-enter <= } \\
.050 \text {, Probability-of-F-to-remove }>=.100 \text { ). }\end{array}$ \\
\hline 2 & Reliability & . & $\begin{array}{l}\text { Stepwise (Criteria: Probability-of-F-to-enter }<= \\
.050 \text {, Probability-of-F-to-remove }>=.100 \text { ). }\end{array}$ \\
\hline 3 & Assurance factor & . & $\begin{array}{l}\text { Stepwise (Criteria: Probability-of-F-to-enter }<= \\
.050 \text {, Probability-of-F-to-remove }>=.100 \text { ). }\end{array}$ \\
\hline
\end{tabular}

. Dependent Variable: Credit risk

Model Summary

\begin{tabular}{|c|c|c|c|c|c|c|c|c|c|}
\hline \multirow[b]{2}{*}{ Model } & \multirow[b]{2}{*}{$\mathrm{R}$} & \multirow[b]{2}{*}{ R Square } & \multirow[b]{2}{*}{$\begin{array}{l}\text { Adjusted R } \\
\text { Square }\end{array}$} & \multirow[b]{2}{*}{$\begin{array}{l}\text { Std. Error of } \\
\text { the Estimate }\end{array}$} & \multicolumn{5}{|c|}{ Change Statistics } \\
\hline & & & & & $\begin{array}{l}\text { R Square } \\
\text { Change }\end{array}$ & F Change & df1 & df2 & Sig. F Change \\
\hline 1 & $.946^{\mathrm{a}}$ & .896 & .891 & .13783 & .896 & 197.294 & 1 & 23 & .000 \\
\hline 2 & $.987^{\circ}$ & .975 & .973 & .06904 & .079 & 69.665 & 1 & 22 & .000 \\
\hline 3 & $1.000^{c}$ & 1.000 & 1.000 & .00000 & .025 & . & 1 & 21 & . \\
\hline
\end{tabular}

a. Predictors: (Constant), Credit monitoring

b. Predictors: (Constant), Credit monitoring, Reliability

c. Predictors: (Constant), Credit monitoring, Reliability, Assurance factor

reliability /variables=q5 q6 q7 q8 /scale ('credit monitoring') all /model=alpha /summary $=$ total.

Reliability

\section{Scale: Credit monitoring}

\section{Case Processing Summary}

\begin{tabular}{|ll|l|l|}
\hline & & N & $\%$ \\
\hline Cases & Valid & 25 & 100.0 \\
& Excluded $^{\mathrm{a}}$ & 0 & 0 \\
& Total & 25 & 100.0 \\
\hline
\end{tabular}

a. Listwise deletion based on all variables in the procedure.

\section{Reliability Statistics}

\begin{tabular}{|l|l|}
\hline $\begin{array}{l}\text { Cronbach's } \\
\text { Alpha }\end{array}$ & N of Items \\
\hline 858 & 4 \\
\hline
\end{tabular}


Item-Total Statistics

\begin{tabular}{|l|l|l|l|l|}
\hline & $\begin{array}{l}\text { Scale Mean if Item } \\
\text { Deleted }\end{array}$ & $\begin{array}{l}\text { Scale Variance if } \\
\text { Item Deleted }\end{array}$ & $\begin{array}{l}\text { Corrected Item- } \\
\text { Total Correlation }\end{array}$ & $\begin{array}{l}\text { Cronbach's Alpha if } \\
\text { Item Deleted }\end{array}$ \\
\hline $\begin{array}{l}\text { Are the officers well aware of } \\
\text { credit monitoring? }\end{array}$ & 4.9200 & 5.243 & .710 & .608 \\
$\begin{array}{l}\text { Is there any training program and } \\
\text { evaluation system for the } \\
\text { officers? }\end{array}$ & 5.0400 & 5.373 & .856 \\
$\begin{array}{l}\text { Do you think the process which is } \\
\text { followed by the bank for } \\
\text { monitoring credit is sufficient? } \\
\begin{array}{l}\text { Does the customer credit rate } \\
\text { depend on credit monitoring } \\
\text { result? }\end{array}\end{array}$ & 4.6800 & 4.560 & .801 & .776 \\
\hline
\end{tabular}

RELIABILITY /VARIABLES=q1 q2 q3 q4 /SCALE ('Reliability') ALL /MODEL=ALPHA /SUMMARY=TOTAL.

\section{Scale: Reliability}

Case Processing Summary

\begin{tabular}{|ll|l|l|}
\hline & & $\mathrm{N}$ & $\%$ \\
\hline Cases & Valid & 25 & 100.0 \\
& $\begin{array}{l}\text { Excluded }^{\mathrm{a}} \\
\text { Total }\end{array}$ & 0 & 0 \\
& 25 & 100.0 \\
\hline
\end{tabular}

Reliability Statistics

\begin{tabular}{|l|l|}
\hline $\begin{array}{l}\text { Cronbach's } \\
\text { Alpha }\end{array}$ & N of Items \\
\hline 617 & 4 \\
\hline
\end{tabular}

a. Listwise deletion based on all variables in the procedure.

Item-Total Statistics

\begin{tabular}{|l|l|l|l|l|}
\hline & $\begin{array}{l}\text { Scale Mean if Item } \\
\text { Deleted }\end{array}$ & $\begin{array}{l}\text { Scale Variance if } \\
\text { Item Deleted }\end{array}$ & $\begin{array}{l}\text { Corrected Item- } \\
\text { Total Correlation }\end{array}$ & $\begin{array}{l}\text { Cronbach's Alpha if } \\
\text { Item Deleted }\end{array}$ \\
\hline $\begin{array}{l}\text { Are the officers well aware of } \\
\text { credit monitoring? } \\
\text { Is there any training program and } \\
\text { evaluation system for the } \\
\text { officers? }\end{array}$ & 4.9200 & 5.243 & .710 & .819 \\
$\begin{array}{l}\text { Do you think the process which is } \\
\text { followed by the bank for } \\
\text { monitoring credit is sufficient? } \\
\begin{array}{l}\text { Does the customer credit rate } \\
\text { depend on credit monitoring } \\
\text { result? }\end{array}\end{array}$ & 4.6800 & 5.373 & .608 & .856 \\
\hline
\end{tabular}

RELIABILITY /VARIABLES=q9 q10 q11 q12 /SCALE ('Assurance factor') ALL /MODEL=ALPHA /SUMMARY=TOTAL. 


\section{Macrothink}

\section{Scale: Assurance factor}

Case Processing Summary

\begin{tabular}{|ll|l|l|}
\hline & & N & $\%$ \\
\hline Cases & Valid & 25 & 100.0 \\
& Excluded $^{\mathrm{a}}$ & 0 & 0 \\
& Total & 25 & 100.0 \\
\hline
\end{tabular}

Reliability Statistics

\begin{tabular}{|l|l|}
\hline $\begin{array}{l}\text { Cronbach's } \\
\text { Alpha }\end{array}$ & N of Items \\
\hline 535 & 4 \\
\hline
\end{tabular}

a. Listwise deletion based on all variables in the procedure.

Item-Total Statistics

\begin{tabular}{|c|c|c|c|c|}
\hline & $\begin{array}{l}\text { Scale Mean if Item } \\
\text { Deleted }\end{array}$ & $\begin{array}{l}\text { Scale Variance if } \\
\text { Item Deleted }\end{array}$ & $\begin{array}{l}\text { Corrected Item- } \\
\text { Total Correlation }\end{array}$ & $\begin{array}{l}\text { Cronbach's Alpha if } \\
\text { Item Deleted }\end{array}$ \\
\hline $\begin{array}{l}\text { Does your bank need to add } \\
\text { strong clauses in the agreement } \\
\text { to get assurance about } \\
\text { repayment loans? }\end{array}$ & 4.9000 & 2.833 & .590 & .486 \\
\hline $\begin{array}{l}\text { Dose assurance factor increase } \\
\text { reliable customer? }\end{array}$ & 4.8000 & 2.550 & .604 & .394 \\
\hline $\begin{array}{l}\text { Does assurance factor reduce } \\
\text { credit risk of the bank? }\end{array}$ & 5.7200 & 3.890 & .198 & .774 \\
\hline $\begin{array}{l}\text { Can a customer get loan easily } \\
\text { with strong assurance? }\end{array}$ & 6.6400 & 3.540 & .344 & .674 \\
\hline
\end{tabular}

\section{Copyright Disclaimer}

Copyright reserved by the author(s).

This article is an open-access article distributed under the terms and conditions of the Creative Commons Attribution license (http://creativecommons.org/licenses/by/3.0/). 